\title{
Lívia Horgos
}

\section{Thought fragments of Preliminary Session in Relation to Accusation and Evidentiary Procedure $^{1}$}

'Aetas semper aportat aliquid novi.'

('Each era brings something new.')

\begin{abstract}
The present study focuses on preliminary session, which was altered in its function by the resolutions of the new Law of Criminal Procedure (entering into force in 2018), that is Act XC of 2017 (henceforth LCP) with special regard to the relationship between accusation and evidentiary procedure with the help of a case. I also examine the rules of criminal procedure codified in Hungarian judicature, the function and influence of preliminary session, the main characteristics and the place of preliminary session among procedural forms of court procedures. The study examines whether preliminary session regulated by LCP meets the requirements and checks indictment eliminating unsubstantiated procedures. In case it fails to do so, what further regulations are needed to be added to present ones in order to meet requirements with special regard to codification policy embodied in criminal judicature, especially effectiveness, promptness, simplicity and coherence. I examine in details the possibility whether it could be the right and obligation of the court to examine not only the means of evidence deriving from legal elements and other informative elements contained in the presented indictment but also the legality of preliminary sessions and investigation procedures as a legal condition of initiating a court procedure. The study describes the regulation of LCP concerning evidentiary procedures in the preliminary session emphasizing the modifications by Act XLIII of 2020 concerning the interrogation of the accused. I examine its significance and point out whether anomalies in connection with the limits of evidentiary procedure are successfully eliminated in judicature.
\end{abstract}

1 The project TKP2020-NKA-09 was completed with the support of the National Research Development and Innovation Fund and financed by the Thematic Excellence Program 2020. 
Keywords: preliminary session, unsubstantiated indictment, limits of evidentiary procedure, interrogation of the accused

\section{Introduction}

The legislator was influenced by the notion of exceeding and safeguarding when codifying the Act XC of 2017 (henceforth Be). One of its key measures is the reinterpretation of the function of the earlier marginal but now obligatory preliminary session. Besides ensuring guarantees for a just procedure it also created an opportunity for simpler and quicker procedures. During preliminary procedures the content, means and methods of defense and accusation are separated from the administrative measures based on accusation. At preliminary procedures the accused party may realize a complex form of cooperation, and it is also an important scene of the concentration of evidentiary procedure since the parties have the opportunity to decide the direction of evidentiary procedure under judicial control. ${ }^{2}$

\section{A Historical Overview of Hungarian Legal Institutions Concerning Preliminary Procedure}

\section{Act XXXIII of $1896^{3}$ (Bp.)}

In modern 19th century codes of procedure indictment division was an institution independent from the public prosecutor and had a controlling role after indictment. The indictment division had preventive aims: unsubstantiated accusation could not reach the court, and no unsubstantiated judicial procedure could be initiated.

During its codification the importance and role of just accusation, including the merit or groundlessness of accusation, were debated in Hungary. According to Ferencz Finkey (Finkey, 1903) a condition of a judicial procedure is a substantiated accusation - based on Art. 1 of Bp. - which has to be examined prior to a judicial procedure.

Bp. accepted the notion of judicial procedure from the contemporary British judicature, the institute of indictment division from French judicature and the form of facultative procedure from Austrian judicature. In Bp. accusation was

2 Law XC of 2017 explanation of criminal procedure.

3 Article of Law XXXIII of 1896 of criminal code of procedure. 
examined by the indictment division in a so called facultative accusatory procedure. This procedure was oral and contradictorily.

'Prior to the main procedure, since it is open to public and implies greater moral and financial disadvantages for the accused party, in modern codes of procedure based on either accusatorial or mixed systems, a separate judicial body examines the issue thoroughly and impartially [...]' (Finkey, 1903).

The members of the indictment division were three judges who may not be judges at the trial. The procedure began after presenting the indictment by the prosecutor, within eight days after the disclosure of the indictment if the accused party filed complaints against the accusation. Bp. ensured the rights to complain about every point of the accusation only for the accused party ${ }^{4}$, but if it does not exercise this right the case may proceed to the main trial without this procedural phase.

'The complaint is a kind of defense argument by the accused party, by which he opposes the accusation and not the court [...]' (Angyal, 1915-1917). The complaint may refer to the evidence of the accusation and its legal and material conclusions. During the session of the indictment division first the defense and then the accusation could address, but the final address was always made by the defense. It must be emphasized that the members of the indictment division could put up questions but could not present new evidence. As the indictment division considered it necessary new investigation or additional-investigation could be ordered, and if there was no investigation it could order one. ${ }^{5}$ In the case of private accusation accusatory procedure was obligatory regardless from the complaints of the accused party. ${ }^{6}$

The indictment division could refer the case, suspend the procedure, order new investigation but it also could terminate the procedure (for example the accusation was unsubstantiated, evidence against the accused party was not enough to prove suspicion beyond reasonable doubt). In the latter case the punitive power of the state could not materialize since the termination decree was equal to acquittal (of res iudicata effect) thus it had to be explained (Finkey, 1903).

The indictment division issued an indictment decree (Angyal, 1915-1917). As the indictment division issued an indictment decree it decided on an indictment $^{7}$, and there was no possibility for legal remedy ${ }^{8}$, thus the accused became

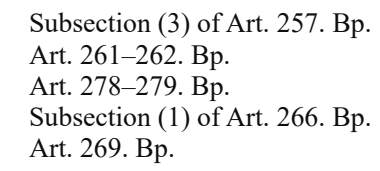


the subject of a legal procedure. ${ }^{9}$ The indictment division had an option to order additional investigation or obtain new evidence. ${ }^{10}$

Act XXIX of $1921^{11}$

This law impaired the rights of the indictment division as it narrowed the scope of complaint by the accused party in some cases (e.g., assault, larceny, embezzlement). The accused party could make a complaint against every point of the indictment in a written form, which had to be presented to the court of the trial, which could terminate the procedure with a decree without trial. ${ }^{12}$

Act XIV of $1946^{13}$

This law eliminated the institution of indictment division. The indictment had to be presented to the court by the accuser to the presiding judge of the judicial body regardless of previous investigations. The accused party still had the right to comment, and the court could refuse the indictment (Belovics, 2018).

Act III of $1951^{14}$ (II. Bp.)

The preliminary procedure belonged to the presiding judge, who studied the case and transferred it to court procedure or presented it to the council in order to take necessary measures. ${ }^{15}$

The novella modifying II. Bp - Act V of $1954^{16}$ (Bpn.) - reregulated and introduced the institute of preliminary session. According to it, in serious cases - when punishment exceeded 2 years of imprisonment, or the accused was in pre-trial detention - a preliminary session had to be held. ${ }^{17}$

During the preliminary procedure the following points were examined: whether the committed act by the perpetrator is a criminal act or not, necessary evidence for a substantiated accusation, whether the indictment contains the right legal classification of the act and they are in accordance with the rulings of II.

9 Subsection (4) of Art. 13. Bp.

10 Art. 262. Bp.

11 Article of Law XXIX of 1921 on the simplification of criminal justice.

12 Subsection (2) of Art. 3 of Law XXIX of 1921.

13 Article of Law XIV of 1946 on termination of indictment division, facilitating press procedures and termination of state penitentiary, I chapter.

14 Law 1951 of III. on criminal code of procedure.

15 Subsection (1) of Art. 139. II. Bp. (effective from 22.05.1951.)

16 Law 1954 of V. modification of the Law III of 1951 on criminal code of procedure.

17 Subsection (1) of Art. 139. II. Bp. (effective from 01.08.1954.) 
Bp. ${ }^{18}$ Based on it the court was entitled to accept the indictment, modify it or order additional investigation - thus accepting the examination of the merit of the accusation - or suspend or terminate the procedure. ${ }^{19}$

During the preliminary procedure the case could not be heard on the merit, it only checked whether the indictment was substantiated and earlier investigation was lawful. The task of the preliminary procedure is to avoid breach of procedural laws and to prevent an unlawful and unsubstantiated case from hearing (Király, 2003).

\section{Law-decree 8 of $1962^{20}$ (I. Be.)}

I. Be. modified the rulings concerning the almost universally obligatory preliminary procedure. It narrowed the scope of obligatory preliminary procedure and in certain cases it entitled the presiding judge to order preliminary procedure if he finds it necessary ${ }^{21}$ (Király, 2003).

\section{Act I of $1973^{22}$ (II. Be.)}

II. Be. codified that as a principle, court procedure may be initiated only on the base of lawful indictment. According to the criminal procedural concept of II. Be., it separated the rulings of preliminary procedure from rulings concerning criminal acts and those of misdemeanor. ${ }^{23}$

The court in basic procedures made decisions at panel meetings during the preparatory phase but if the hearing of the prosecutor or the perpetrator proved to be necessary prior to issuing a decree it held a preliminary session. Preliminary session was obligatory when the court sent back the documents to the prosecutor (additional investigation) ${ }^{24}$. During the preparatory phase II. Be. made besides the suspension or termination of a case an additional investigation possible as well. ${ }^{25}$

In misdemeanor procedures the rulings of criminal procedures had to be applied during the preliminary phase if the judge referred the case to the council. To reveal the complete conclusion of facts the court could send back the documents

18 Subsection (2) of Art. 140. II. Bp.

19 Subsection (3) of Art. 140. II. Bp.

20 Law-decree 8 of 1962 on criminal procedure.

21 Art. 170. I. Be.

22 Law I of 1973 on criminal procedure

23 II. Be. Chapter VIII. Title II. Preparation of the Hearing in Misdemeanour Procedures

24 Subsection (1)-(2) of Art. 176. II. Bp.

25 Subsection (1) of Art. 171. II. Bp. 
of the case to the prosecutor if the investigation was conducted according to the rulings of misdemeanor but without its legal conditions. ${ }^{26}$

\section{Act XIX of $1998^{27}$ (III. Be.)}

The previous $\mathrm{Bp}$. and the other laws regulating criminal procedure did not codify the notion of lawfulness of accusation but the accusation had to be examined concerning its lawfulness prior to hearing. This examination considered the investigation and the merit of the accusation thus the court was entitled to review it. The notion of legal charge became part of III. Be. by the Act LI of $2006^{28}$ as this act defined the requirements concerning formality and minimal content. ${ }^{29} \mathrm{It}$ did not codify the notion of merit as a criterion of legal charge.

According to my viewpoint the accusation is substantiated if the motion to the court contains serious suspicion based on substantiated evidence. If the indictment does not meet this requirement, unsubstantiated court procedure cannot be conducted. One of the reasons for it might be the inadequate investigation full of mistakes, which is due to the inadequate controlling and supervising activity of the public-prosecutor's office. The public prosecutor has to notice if further investigative procedures could lead to any result or not - and it fails to do so and presents and indictment. The demolishing of the punitive power of the state resulting from inadequate work by the public prosecutor must be due to the public prosecutor, who has to be responsible for it (Horgos, 2021).

In the case of III. Be. additional investigation could not be ordered in the preparatory phase.

III. Be. distinguished the obligatory and optional version of preliminary procedure. Preliminary procedure was obligatory if the court decided on pre- trial detention, house arrest or temporary involuntary treatment in a mental hospital or if the accused party or the defense proposed the termination of the special protection of witness. ${ }^{30}$ Preliminary session was possible if during the preparatory phase the hearing of the prosecutor or the accused party seemed necessary prior to the verdict. ${ }^{31}$

While in $\mathrm{Bp}$. the institute of indictment division was a checking method in this law it eliminates unsubstantiated accusation. In this process it has the opportunity

26 Subsection (1)-(2) of Art. 186. II. Bp.

27 Law XIX of 1998 on criminal procedure.

28 Law LI of 2006 on modification of Law XIX of 1998 on criminal procedure.

29 Subsection (1)-(2) of Art. 2. III. Bp.

30 Subsection (2) of Art. 272. III. Bp.

31 Subsection (1) of Art. 272. III. Bp. 
to accuse the defendant but it also prepared the main hearing at the same time. Contrary to it at the preparatory session indictment was not questioned since the prosecutor had already indicted the accused party.

I agree with the opinion of Ervin Belovics that in the present system the preparatory procedure cannot be equal to the indictment procedure codified in Bp. since the presentation of the indictment has taken place but the examination of the merit of the accusation was omitted because the preparatory procedure aims only at the preparation of the hearing. (Belovics \& Tóth, 2020). On the contrary, at the indictment procedure codified by Bp. the indictment division examines the indictment prior to indictment itself. This institute also has a hearing preparatory function.

In my opinion, it is valid only for hearing preparation codified only in III. Be. - similar to operative Be. - since earlier laws offered the possibility of examining the merit of the accusation after indictment.

According to the Curia the acting court is legally not entitled to examine the preparation of the indictment, or the investigation (merit of the accusation), since if it had acted so - ex officio - it would review the decision of the prosecutor concerning indictment. ${ }^{32}$ The Constitutional Court separated the issue of the merit of indictment and lawfulness of it, as the lawfulness is a necessary precondition of initiating a hearing while merit can be proved as a result of the activity of the court. ${ }^{33}$ Concerning these opinions it is a central issue whether merit is part of the legality of indictment or not. There are opposing views in relevant special literature. According to one view - which I agree with - merit of indictment is part of its legality since legal accusation must be based on evidence gathered legally. Indictment has to contain the argument of the prosecutor that the evidence is sufficient to prove the guiltiness of the accused party beyond any doubt. If indictment fails to meet this requirement it excludes the legality of the indictment based on illegally acquired evidence (Gellér, 2011). According to the other view merit is not part of lawfulness of indictment since the lawfulness of indictment does not require substantiated evidence (Fantoly, 2016).

\section{The New and Significant Role of Preparatory Session in Be. and in Relation to Evidentiary Procedure}

The institute of Preparatory Section was completed in its function and made more significant by Be. but it did not revive certain rights of the indictment

32 Final ruling of Curia, Bfv. I.1559/2012/4.

33 Rulings by the Constitutional Court, 33/2013. (XI. 22.) 
division. Although during the codification of Be. the introduction of additional investigation in accordance with the requirements of contradictorily procedure was considered - albeit in a new form - in order to prepare court hearing (Handó, 2013). It did not happen.

According to Subsection (1) of Art. 499 of Be.: 'The preparatory session follows indictment and an open session in order to prepare the hearing, during which both the prosecutor and the accused party may express their opinion concerning indictment and contribute to the formation of the course of criminal procedure.'This contribution is ensured for the accused party either confessing or not confessing the criminal act the hearing is based on. Besides ensuring guarantees for the elements of just procedure Be. makes it possible to simplify and accelerate the procedure.

At the preparatory session the presence of the prosecutor and the accused party is obligatory, but evidentiary procedure cannot be conducted due to its open characteristics. The function of the institute is to prepare the hearing. If a public defender takes part in the process, preparatory session cannot be held without a public defender. ${ }^{34}$

After the beginning of the preparatory session the prosecutor reads the essence of the indictment upon the request of the judge and he names the means of evidence. It must be emphasized that the prosecutor may make an alternative proposal concerning the extent and length of the punishment if the accused party confesses guilty at the preparatory session. ${ }^{35}$ In this case the accused party can be aware in advance of the preference he may have if he confesses guilty. It is followed by the questioning of the accused party. ${ }^{36}$

The preparatory session - as I have earlier mentioned, the cooperation with the accused party - became an integral part of the complex system of Be. since it provides an opportunity to avoid hearings. If the accused party confesses guilty in the criminal act, the subject of the accusation, and renounces his right to a trial and the court accepts his confession, decision can be made in this phase of the procedure. In this case the procedure is carried out according to rulings valid for confessions of guilt. ${ }^{37}$

If the accused party does not confess guilty at the preparatory session the procedure is carried out according to the rulings valid for confessions of not guilty. ${ }^{38}$

34 Subsection (5) of Art. 499. Be.

35 Subsection (1) of $\S 502$. Be.

36 Subsection (3) of $\S 502$. Be.

37 Art. 504. Be. - Subsection (1) of Art. 505. Be.

38 Subsection (3) of Art. 506-508. Be. 
The Be. omitted the adjective 'legal' - constituting a fundamental requirement - in front of the noun 'accusation' and does not define the notion of legal accusation. Be. also abolished the distinction between legal accusation and deficient accusation codified in III. Be. But the legal requirements of the accusation can be derived from rulings of Be. concerning other accusations.

Be. took over the concept from III. Be that it does not examine the merit of the accusation during the preparatory phase or at the preparatory session. Be. does not dispose the formal control of possible unsuitable (unsubstantiated) accusation prior to the hearing during the preparatory phase. At the preparatory session there is no relevant ruling, which should be added. According to my view it would not infringe the principle of the division of procedural functions, since accusation and ruling would not be united at the court. As Pál Angyal wrote: it would concern with formal examination and not substantial evaluation of evidence (Angyal, 1915-1917).

If at the preparatory session after indictment the evidence against the accused party proves to be insufficient then further evidence becomes irrelevant. In this case the termination of the procedure should be allowed at the preparatory session.

I believe that at a preparatory session concerning an accused party confessing not guilty and his defense the presentation of their view on accusation functions only theoretically. If the accused party and his defense refer to the groundlessness of the accusation at the preparatory session, it does not imply any relevance since it does not result in any legal consequence according to the rulings of Be. The hearing will be scheduled, where the court can examine the role and quality of evidence on the merit. In this way the other main function of the new role of the preparatory session, the concentrated hearing preparation is emphasized, when the accused party and his defense play an active role at the preparatory session in shaping the further course of the criminal procedure, defining the direction and limits of evidence.

If the accused party confesses not guilty, he may name those facts of the indictment, the reality of which he accepts at the preparatory session. ${ }^{39}$ The accused party and the defense may present an evidentiary motion or evidence excluding motion at this phase. ${ }^{40}$ In this case the significance of the preparatory session is realized in defining the later direction of the evidentiary procedure. Thus, the preparatory session has a decisive role in the concentration of evidentiary procedure.

39 Subsection (3) of Art. 506. Be.

40 Subsection (4)-(5) of Art. 506. Be. 
It must be added that the preparatory session is the last procedural act where the prosecutor, the defense and the accused party may submit a motion without the consequences codified in Subsection (5)-(6) of Art. 520. Be. The accused party and the defense may be fined by the court if the defense cannot prove that the evidence originated after the preparatory session, or he learnt about it after the preparatory session through no fault of his own, or the motion tries to weaken earlier evidence or denies the result of evidentiary procedure if its method, means became known to him after the completed evidentiary procedure. ${ }^{41}$

\section{The ban and possibility of evidence at the preparatory session}

The evidentiary procedure in a criminal procedure is a complex and direct cognitive procedure, whose aim is to define criminally relevant past conclusion of facts of a given case by the acting authority especially by the court. It contains the collection, examination and evaluation of evidence and lasts from the suspicion to the certainty. Evidentiary procedure is the central element of the criminal procedure since the successful realization of the punitive power of the state depends on it and the criminal liability as well. Evidentiary means are procedural activities or objects from which the investigator, the prosecutor, the judge and other parties in the procedure can get information concerning the perpetrator and the criminal act (Király, 2003). The confession of the accused party is means of evidence. Confession is any statement made by the accused party during the criminal procedure after being warned and in which he states any fact relevant to the object of evidence. ${ }^{42}$

At the beginning the preparatory session was equal to the session among procedural forms, but later the preparatory session regulated in Be. became a special form of public trial. Both trials and public trials deny the introduction of evidence, and the evidentiary procedure. In spite of it when Be. came into force the accused party had to be interrogated at the preparatory session according to the capital of XXX of Subsection (3) of Art. 502. of this ruling was modified by Point 87 of Art. 271 of Act XLIII of $2020^{43}$ entering into force on 1st January, 2021. According to it the court has to interrogate the accused party with a social regard to the character of the preparatory session. At this modification the legislator took the judicial practice as a basis, but it is expressed unambiguously in the explanation of the modified law.

41 Subsection (1)-(2) of Art. 520. Be.

42 Subsection (1) of Art. 183. Be.

43 Law XLIII of 2020 on modification of the law of criminal procedure and other laws. 
Until the modification of Be. judges tried to create a judicial practice in order to prevent the serious infringement of the ban of evidentiary procedure required at public hearings. According to it, evidentiary procedure may take place at preparatory sessions. Evidentiary procedure is allowed only if it is a confession of guilt by the accused party but it is forbidden if it exceeds that. The right of interrogation is valid but it must be documented that there is no possibility to present earlier confessions of the accused party at the preparatory session. Confession made at the preparatory session does not substitute the confession made at the trial (Laczó \& Pecze, 2020).

The accused party cannot be obliged to make a confession at the preparatory session, he can live with the right of silence. His silence has to be regarded as a denial of guilt. The accused party can deny to make a confession at the preparatory session. The court has a wide scope of obligations concerning the information and warning of the accused party (Elek, 2018). According to Art. 185. of Be. the court has to inform the accused party about the issues codified in a)-d) Points of Subsection (2) of Art. 500. Be.

Then the court - as I have earlier mentioned - questioned the accused party according to capital XXX of Be. until 31st December 2020, and since 1st January 2021 with special regard to the characteristics of the preparatory session. The main question of the court is to the accused party at the preparatory session whether he confesses guilty or not in the criminal act tried at the court.

I must mention that in the procedure of second instance the hearing of the accused party concerning the circumstances of punishment may not be regarded as evidentiary procedure. ${ }^{44}$ If the court of second instance wishes to accept evidence it has to function according to trial forms. At trials of first instance, if the accused party made a confession - with the consent of the defense - his interrogation concerning those statements made by him at the preparatory session can be omitted. ${ }^{45}$

\section{A Case $^{46}$}

The examination of the case with a final judgement at the trial of second instance focuses especially on the subject of the present study and demonstrates the effect of an unsubstantiated accusation on a court procedure. Furthermore,

44 Subsection (2) of Art. 599. Be. and Point b)

45 Subsection (1) of Art. 222. Be.

46 The detailed account of the trial of first instance and the trial of second instance in not relevant in respect of my study 
it provides a case study of accusation and evidentiary procedure (interrogation of the accused party) through the function of preparatory session in judicature.

\section{Investigation, Accusation and Critic}

The investigating authority accused M. L., an Italian citizen, with clean criminal record (henceforth the accused in the investigative phase) at his interrogation on 22nd August, 2012 on the base of having committed a criminal offense in breach of $\S 202 / A$ on the basis of the following facts, based on IV. Act of the Penal Code still in force on 22 August 2012.

The accused met J. O., a prostitute (henceforth the aggrieved) born 13th February, 1998, between October 2011 and February 2012 in Népliget, a park in the 10th district of Budapest, on undefined dates, and they agreed on having a sexual intercourse for consideration. According to this agreement the accused met the aggrieved party about 5 times, sometimes in the flat of the accused, sometimes in the 10th district, in Népliget. At these occasions the accused had oral sex with the aggrieved party several times and the accused had once anal sex with the aggrieved party. The accused gave 10.000-20.000 Forints to the aggrieved party for the sexual intercourse at occasions.

The accused was aware that at the time of the act the aggrieved party was under 18, the aggrieved party told him he was over 16.

The accused, who denied committing criminal act, said during the interrogation that he had been in Népliget several times in order to collect information for his book on sociology, and a planned newspaper article - as he was a journalist - he studied the lives and habits of homeless people. He stated that he only spoke and had no homosexual connections with the men and boys he met in Népliget, not even with the aggrieved party since he did not know him. Otherwise, he is not homosexual, he has a wife, and he is ill, and in the last phase of Parkinson disease.

During the investigation the followings were recorded:

- The aggrieved party describes 'the Italian' as a thin man, $180 \mathrm{~cm}$ high, who can speak Hungarian. The aggrieved party met 'the Italian' 5-6 times even in his flat. The accused were suffering from Parkinson disease at this time. The aggrieved did not notice the physiological symptoms, for example trembling of the right hand.

- The investigative authority describes the accused in its report of 8th May, 2012 as a chubby man, walking with a stick, and cannot speak Hungarian. The aggrieved party stated in his confession of 24th July, 2012 that 'the Italian' spoke Hungarian from the beginning. 
- Witness M. K. stated on 2nd May, 2012 that when he was looking for his son (the aggrieved party) he saw a black Mercedes, which he stopped and showed the photo of his son. The driver spoke Hungarian, but in a strange way, as if he had accent, he called him 'the Italian'.

- Witness N. Sz. (female) stated on 15th April, 2013 that she also spoke with the accused but in English and not in Hungarian. She stated that the accused was a regular customer of hers. She did not know that the accused had sexual connections with gay and transsexual people.

- Witness R. P. stated on 18th October, 2012 that he had never seen the accused walking with men or boys, he described him as someone who was peeping on pairs. He watches them and it makes him entertained. This statement is contained in the police report, where the behavior of the accused is described. The witness looking at the photo of D. E. said, that he has a black Mercedes and is known as 'Sanyi', with whom she had 'business' several times earlier.

Summary:

1) The investigation did not reveal the number plate and owner of the black Mercedes visiting Népliget during the interval of the case. Relevant evidentiary procedure could not be ordered at the trial.

2) The identity of 'the Italian' and the accused was not examined, whether they are the same person or two different ones, even if there were serious doubts.

3) The physical appearance of the accused was not examined, albeit there were contradictory statements.

4) The aggrieved party made confessions several times during the investigation, which were different and newer and newer statements were added in a way that the recognition of the accused from a photo and at the introduction were not unambiguous. In spite of all this according to the investigative authority and the prosecutor the aggrieved party recognized the accused party.

5) During the investigative procedure the accused and the aggrieved party were not confronted. Due to the deficiency of the investigation (indictment) relevant facts were not revealed, contradictions were not solved, but indictment was made.

\section{Accusation}

The District Prosecutor's Office of the tenth and seventeenth districts submitted the indictment to the Pest Central District Court on January 7, 2015. The 
facts of the indictment were presented in the same way as the facts at the time of the suspicion, but the offense was classified according to new Criminal Code (Act C of 2012 on the Penal Code). Pursuant to Section 203 (2), the prosecutor's office charged the accused with the crime of using conflicting and qualifying child prostitution. The District Prosecutor's Office of the tenth and seventeenth districts proposed in the indictment that the accused be sentenced to imprisonment, the execution of which should be suspended by the court for a probationary period.

\section{Preparatory Session and Critic}

The accused party did not confess guilty at the preparatory session of 4th January 2019 according to the regulations of Be. in force.

The accused did not want to make a confession at the 'interrogation' but answering to the questions of the acting judge he made a detailed confession, as a result the questioning of the accused at the main trial was not necessary. Answering the questions, he said the most important things that he had already said during the investigation. The court of first instance presented the confession of the accused.

The court of first instance neglected the preparatory characteristics of the session, the earlier mentioned judicial practice, according to which evidentiary procedure may not be held to such a degree at a preparatory session.

The defense presented its viewpoint and motion in a written form in connection with the accusation according to Subsection (3) and (4) of Art. 506. Be. mentioning the contradictions perceived during investigation.

At the preparatory session the defense presented its viewpoint on the accusation referring to the unsubstantiated accusation according to Subsection (1) of Art. 499. Be. The defense mentioned that only that fact in the indictment can be accepted that the accused party had been in Népliget several times, he watched the people there and had no homosexual connection with either boys or men, and he did not pay for any. The defense pointed out that the accused party had not committed the criminal act stated in the accusation thus his culpability cannot be defined.

Other motions by the defense were in connection with the conduct of evidentiary procedure and other procedural activities based on Subsection (4) of Art. 505 . Be. proposing questioning of witnesses and the delegation of a psychiatric expert. 


\section{Trials at the court of first instance}

The date of the first trial was on 6th March, 2019, later the court of first instance set 4 days of hearing during which it conducted the evidentiary procedure. The accused party renounced his right to be present at the trial after the first occasion. At the trial on 22nd November, 2020, the court of first instance found the accused party guilty in absentia in the cumulative offence of child prostitution codified in Subsection (2) of Art. 203. Btk. based on the evidentiary procedure. The court sentenced the accused party 6 months of imprisonment - with a probation of 1 year. ${ }^{47}$

The state-attorney appealed for severity while the accused party and the defense appealed firstly for acquittal, secondly for mitigation of the sentence.

\section{Trial at the court of second instance}

Based on the appeal the court of second instance set the date of a public hearing on 21st October, 2020 based on the Subsection (1) of Art. 590. Be. and reviewed the previous procedure in full length and the appealed sentence.

The court of second instance - partly because of the content of the appeal by the defense - found a new evidentiary procedure and the questioning of witnesses substantiated - based on Subsection (1) of Art. 600. Be. - and set the date of a hearing based on Subsection (1) of Art. 600. Be. At this hearing on 27 th January 2021 the court completed the evidentiary procedure and delivered a judgement of second instance. ${ }^{48}$

The court of second instance modified the sentence of the court of first instance based on Point b) of Subsection (1) of Art. 604. Be. and acquitted the accused party from the accusation with the culminate offence of child prostitution referring to Subsection (2) of Art. 606. Be. and Point c) of Subsection (2) of Art. 566. Be. stating that the accused party did not commit the criminal act. As a result of the evidentiary procedure at the procedure of second instance, the court of second instance completed and modified the judgement of the court of first instance in its judgement.

It documented in its judgement that the aggrieved party was the inhabitant of a child care institution K. L. in Budapest in 2011 and 2012 between October 2011 and February 2012 he escaped from the institute with some of his friends

47 The judgement of first instance 14.B.X.31.202/2018/88. of Pest Central District Court of 22nd November, 2019.

48 Final judgement of second instance $32 \mathrm{Bf} 8316 / 2020 / 36$. of Budapest Court of Law of 27th January 2021 coming to force on 28th April, 2021. 
and worked as a prostitute in the 10th district of Budapest, Népliget - for pecuniary consideration. The accused party, an Italian man suffering from Parkinson disease, walking with the help of a stick, and not being able to speak Hungarian, visited Népliget in his Mercedes. He usually watched couples in Népliget and asked them if they agreed on having sex with him. If they agreed he stayed there, if not, he simply left.

Based on the evidentiary procedure conducted by the court of law, it stated that it could not be proved without reasonable doubt that the accused party would have committed the crime. In the given case the confessions of the aggrieved party concerning the accused party were full of contradictions.

The judgement of second instance was accepted by the accused party and his defense, but the state attorney appealed it within 3 workdays. The sentence was rendered definitive in the procedure of second instance since the state attorney withdrew the appeal and there was no need for a hearing of at third instance.

\section{Closing remarks}

According to my viewpoint the new, concentrated hearing preparing function of the preparatory session, which helps to realize the content, means, and methods of accusation and defense at the same time, can be regarded favorably.

I believe that the institute of preparatory session codified in Be. does not meet the requirements according to which unsubstantiated accusation could be selected out by examining the accusation, especially in the case of inadequate accusation. No preparatory session meets the requirements of a constitutional state, which allows court hearings in case of inadequate accusation. It seems to be necessary to broaden the rulings of Be. in a way that the accused party and the defense may propose objection besides presenting their viewpoints concerning inadequate accusation. Based on this objection the court would have to control the formal merit of the accusation besides examining the legal means of evidence deriving from the presented indictment. In this way the court should have the right to terminate the procedure based on Art. 492. of Be.

The legislator did not elaborate completely the rules of the breach of the ban of evidentiary procedure concerning the accused party at the preparatory session. In this respect the above-mentioned modification of Be. did not result in significant development. It remained an unfinished task for the legislator.

I believe that anomalies concerning the limits of evidentiary procedure should not be resolved by judicial practice at the institute of preparatory session, but it should be codified. It seems to be necessary that the breach of the ban of 
evidentiary procedure at the preparatory hearing would be allowed only in case of 'Procedure in case of confessing guilty'.

'The closer we are at the goal, the more complete is the ruling' (Degré, 1914). It is a guarantee for a due process of law as one of the cornerstones of a constitutional state.

\section{References}

Angyal, P. (1915-1917). A magyar büntetöeljárásjog tankönyve [Course book of Hungarian Criminal Procedure.] Athenaeum.

Belovics, E. \& Tóth, M. (2020). Büntető eljárásjog [Criminal Law]. HVG-ORAC Lap és Könyvkiadó.

Belovics, E. (2018). Az előkészítő ülés szerepe a 2017. évi XC. törvényben [The Function of Preparatory Session in Law XC. of 2017.]. In Molnár, G. M. \& Koltay, A. (Eds.), Bonus Iudex. Ünnepi kötet Varga Zoltán 70. születésnapjára [Bonus Iudex. Festive volume for Zoltán Varga's 70th birthday] (pp. 39-53). Pázmány Press.

Degré, M. (1914). A vád alá helyezési eljárásról [About Indictment Procedure]. In Büntetőjogi dolgozatok Balogh Jenö születése évfordulójának ünnepére [Criminal law papers for the celebration of the birth anniversary of Jenő Balogh] (pp. 78-93). Wessely és Horváth Könyvnyomdája.

Elek, B. (2018). Elökészitö ülés [Preparatory Session]. In Polt P. (Ed.), Kommentár a büntetöeljárási törvényhez. 2. kötet [Commentary on the Code of Criminal Procedure] (pp. 1064-1079). Wolters Kluver.

Fantoly, Zs. (2016). Törvényes legyen-e a vád, avagy újabb gondolatok a vádelvről - egy törvénytervezet tükrében [Criminal Law]. In Gál, A. \& Karsai, K. (Eds.), Ad Valorem. Ünnepi tanulmányok Vida Mihály 80. születésnapjára [Ad Valorem. Festive studies for the 80th birthday of Mihály Vida] (pp. 55-66). Iurisperitus Kiadó.

Finkey, F. (1903). A magyar büntető eljárás tankönyve [Course Book of Hungarian Criminal Procedure]. Politzer Zsigmond és Fia.

Gellér, B. J. (2011). A vád törvényességének egyes aspektusai [Certain Aspects of Lawful Indictment]. In Belovics, E., Tamási, E. \& Varga, Z. (Eds.), Örökség és büntetőjog. Emlékkönyv Békés Imre tiszteletére [Inheritance and criminal law. Memorial book in honour of Imre Békés] (pp. 35-48). Pázmány Péter Katolikus Egyetem, Jog- és Államtudományi Kar.

Handó, T. (2013). Elöterjesztés az új büntetőeljárási törvény koncepciójáról szóló Kormányhatározat tervezetéhez, 4. [Proposal to the Draft Of Government Decree on the Concept of New Criminal Procedure] (az OBH Elnökének 30237-32/2013. számú előterjesztése). 
Horgos, L. (2021). A ius puniendi jogállami tartalmának kiteljesedése [The accomplishment of the constitutional content of ius puniendi]. In Szabó, Cs. \& Molnár, D. (Eds.), Studia Doctorandorum Alumnae. Válogatás a DOSz Alumni Osztály tagjainak doktori munkáiból. II. kötet [Selection from the doctoral theses of the members of the DOS Alumni Department. II. volume] (pp. 11-260). Doktoranduszok Országos Szövetsége.

Király, T. (2003). Büntető-eljárásjog [Criminal Procedure Law]. Osiris Kiadó.

Laczó, A. \& Pecze, T. (2020). A 2017. évi XC. tv. (Be.) a birósági eljárást érintő leglényegesebb újitásai [The Most Important Issues of Law XC. of 2017 on court procedure]. Online Lecture 22nd October 2020.

\section{Reference of the article according to APA regulation}

Horgos, L. (2021). Thought fragments of Preliminary Session in Relation to Accusation and Evidentiary Procedure. Belügyi Szemle, 69(SI6), 89-106. https://doi.org/10.38146/BSZ. SPEC.2021.6.6

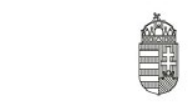

NATIONAL RESEARCH, DEVELOPMENT AND INNOVATION OFFICE HUNGARY
PROJECT FINANCED FROM THE NRDI FUND 